DOI: https://doi.org/10.15407/preislamic2021.02.061

UDC $94(32)$

\title{
QUEEN ANKHESENAMUN AND THE CRISIS OF THE AMARNA DYNASTY
}

\author{
O. A. Zapletniuk \\ $\mathrm{PhD}$ (History) \\ $\mathrm{PhD}$ Candidate in Egyptology \\ Swansea University \\ United Kingdom \\ olga.zapletniuk@gmail.com
}

The article is devoted to the study of the role of Queen Ankhesenamun in the political situation in Ancient Egypt in the Post-Amarna Period and the influence of her activities on the international situation in the Middle East. Ankhesenamun (Ankhesenpaaten) (app. 1345 - after 1323 BC) was a key figure of the Post-Amarna Period, her political actions had an impact on the international situation in the Middle East and she was a prominent figure in the struggle for the Egyptian throne, that led to its usurpation by courtier Ay and final end of the Amarna Dynasty. The crisis of the Amarna Dynasty and transfer of power to the non-royal pretender remains unclear and deliberative. Despite the fact, that in the historiography of the Amarna Period Ankhesenamun remains in the shadow of her famous husband, Tutankhamun, and his successors, the archaeological and narrative sources show that she was an active and very important historical figure, holding political power and acting as the legitimate heir and ruler. The author concludes that the struggle between Ankhesenamun, Ay and Horemheb for the Tutankhamun's throne clearly indicated that Ay and Horemheb were non-royal persons, who later usurped power without legal rights.

Keywords: Ancient Egypt, Ankhesenamun, Tutankhamun, Amarna Period, Akhenaten

\section{O. А. Заплетнюк}

\section{ЦАРИЦЯ АНХЕСЕНАМОН ТА КРИЗА АМАРНСЬКОЇ ДИНАСТІЇ}

Єгипетська цариця кінця XVIII династії (бл. 1539-1077 pp. до н. е.) [Hornung et el. 2006, 492] Анхесенамон (Анхесенпаатон) (бл. 1345-1323 pp. до н. е.) була ключовою постаттю в Постамарнанський період, іï активні політичні дії вплинули на міжнародну ситуацію на стародавньому Близькому Сході. Боротьба Анхесенамон за єгипетський престол призвела до узурпації влади придворним Еє і до падіння Амарнської династії. Анхесенамон стала відомою завдяки відкриттю гробниці їі чоловіка та брата - фараона Тутанхамона, в 1922 р., але в поточних дослідженнях Амарнського періоду вона залишалася в тіні свого чоловіка та його наступників.

Амарнський період в історії стародавнього Єгипту був позначений масштабною релігійною реформою за часів правління фараона Аменхотепа IV (Ехнатона) (пр. 1353-1336 рр. до н. е.), який протиставив фіванському богу Амону новий релігійний культ сонячного диска Атона. Це привело до нового бачення влади фараона, який був проголошений сином Атона, його головним жерцем та медіатором між богом і людьми, який транслював волю свого батька підданим. Монотеїстичний характер нової релігійної ідеології, закріплений у текстах гімнів Атону, який проголошувався “творцем землі всієіิ, що являє себе в людях, стадах, тваринах та деревах", 
богом, “що створив сам себе” [Заплетнюк 2014, 43], не передбачав необхідності в існуванні інших богів, адже Атон, як андрогенний бог в образі сонячного диска на небі, перейняв усі їхні функції для керування світом. Виняткове становище бога Атона призвело до посилення влади самого Ехнатона, який тепер одночасно був політичним та релігійним лідером країни, зміцнивши царську владу та обмеживши вплив на неї з боку фіванського жрецтва бога Амона.

Новий релігійний культ і посилення влади царя вплинули на статус його “Великої царської дружини”, цариці Нефертіті, яка тепер була не просто царицею-консортом, а й дістала божественний статус. У центрі нового культу Ехнатон поставив власну сім'ю, де разом з Нефертіті і богом Атоном вони становили божественну тріаду. Через відсутність пантеону богів і богинь Нефертіті фактично була першою і єдиною божественною персоною жіночої статі. Вона зображувалася з божественними атрибутами і на всіх офіційних сценах перебувала поруч із чоловіком під променями сонячного диска, здійснюючи релігійні обряди. В останні роки правління свого чоловіка Нефертіті під іменем Анхеперура Нефернефруатон була призначена його співправителькою [Dodson 2020, 80].

Анхесенпаатон (з давньоєг. Живе вона для Атона) була третьою із шести доньок Ехнатона та цариці Нефертіті. Згідно з текстами прикордонних стел у новій столиці - Ахетатоні (сучасна Телль ель-Амарна), - збудованої ії батьком, вона народилася в період між 5-м та 8-м роками правління Ехнатона, адже вже на перших прикордонних стелах іï зображення було додано до основної композиції [Murnane 1993, 12-13]. Саме прикордонні стели на місці заснування нової столиці правили офіційною прокламацією встановлення в державі нової ідеології [Заплетнюк 2020, 92]. Анхесенпаатон була центральною постаттю в новому сонячному культі Атона, як ії мати та сестри, зображуючись часто разом зі своїми батьками під променями Атона в церемоніальних сценах підношення та служіння богу сонячного диска, а також у приватних сценах. Царівна Анхесенпаатон з'являється на зображеннях у гробницях в Ахетатоні. На блоці MRAH inv. 4491 із Брюссельського королівського музею значаться ім'я принцеси Анхесенпаатон та сонячний храм на ії честь. Реконструкція напису на блоці також передбачає, що це була частина церемоніальної сцени, на якій були зображені фараон Ехнатон та царівна Анхесенпаатон під променями сонячного диска [Hagen 2011, 216-222].

Після смерті свого батька на 17-му році правління Анхесенпаатон, найімовірніше, залишилася єдиною царівною, що вижила, і у віці 12-13 років стала дружиною молодого спадкоємця (i, найімовірніше, іiі рідного брата) Тутанхатона, якому на момент воцаріння було близько 9 років, здобувши традиційний титул "Великої царської дружини". Напис із гробниці ТТ 139, де згадується “третій рік правління Анхеперура-мері-[...] Нефернефруатон-мері-А[...]" [Dodson 2020, 80], підтверджує факт царювання Нефертіті принаймні протягом перших трьох років після смерті Ехнатона. Залишається невідомо, чи правила Нефертіті як регент при малолітньому Тутанхатоні за прикладом Хатшепсут, і тоді дату їі правління слід вважати третім роком правління Тутанхатона, або ж iї царювання було незалежним. Нефертіті володіла колосальним політичним впливом у роки правління Ехнатона, що могло дати їй змогу зайняти престол після його смерті без оголошення регентства, а наявність спадкоємця чоловічої статі в особі юного Тутанхатона, який міг бути рідним сином Нефертіті, також зміцнювала іiї позиції на престолі. 
Однак без Ехнатона Нефертіті не змогла втримати владу і зберегти позиції культу бога сонячного диска Атона, панування якого й було запорукою іiі політичного статусу. А. Додсон вважає, що на графіті з гробниці ТТ 139 титул Нефернефруатон слід реконструювати як "Нефернефруатон, улюблена Амоном" [Dodson $2020,80]$. Ключовим моментом $€$ те, що напис містить молитву богу Амону жерця і писаря Амона Па-аха, а в самому тексті згадується про функціонування храму Амона у Фівах. Це свідчить про те, що вже на третьому році правління Нефернефруатон Амон не тільки не переслідується, а й жерці його культу знову відкрито проводять богослужіння.

Невідомо, як довго правила Нефернефруатон і що сталося з нею перед воцарінням Тутанхатона, але протягом перших років правління молодого царя стара єгипетська аристократія та жрецтво Амона у Фівах відновили свою владу та вплив. Анхесенпаатон та Тутанхатон опинилися в центрі чимраз більшої хвилі переслідування атонізму та результатів діянь фараона Ехнатона. Молоде подружжя було вивезене з Ахетатона до Мемфіса, їхні царські імена змінені на Тутанх-амон та Анхесен-амон на користь реставрованого культу бога Амона Фіванського. На 4-му році правління Тутанхамона в Карнацькому храмі Амона перед III пілоном була встановлена так звана Реставраційна стела. Дублікат стели стояв також біля входу у храм бога Монту. На стелі зображений Тутанхамон, який здійснює підношення Амону та богині Мут, біля фараона стоїть його дружина Анхесенамон. Реставраційна стела є офіційним баченням релігійної реформи Ехнатона з боку його опозиції. У тексті йдеться: “...Були храми богів та богинь, починаючи з Елефантіна, до самої Дельти... були піддані забуттю, їхні храми лежали в руїнах, що поросли травою. Їхні святилища стали такими, що не існують. Їхні двори стали прохідними. Боги відвернулися від країни: якщо армію посилали до Палестини, то не було успіху. Якщо хтось молився богу і просив його про щось, то не відповідав бог зовсім. Якщо також молився богині, вона не приходила. Їхні серця стали слабкими через їхні тіла. Але після того, як минули ті дні, [Його Величність] з'явився на троні свого батька і почав правити усіма землями Хора. Сгипет та інші країни тепер під його наглядом, кожна земля вклонилася перед його владою... Він (Тутанхамон) дав більше, ніж було раніше: він вшанував свого батька Амона... та усіх інших богів... Він примножив те, що було раніше. Він відновив у посадах жерців... він наповнив рабами і рабинями їхні служби як дари Його Величності... Боги і богині перебувають на цій землі, серця їхні в радості, усі радіють, радощі по всій країні” [Murnane 1995, 212-213].

Відмова від атонізму як загальнодержавного культу призвела до послаблення влади фараона. При малолітньому правителі посилили свій вплив багато придворних, особливо візир Еє та воєначальник Хоремхеб. При Тутанхамоні Хоремхеб дістав титули I dnw n nsw m tA r D=f - “Царський представник в усій країні" [Dodson 2009, 65] та Iry pat nw Smaw tAmHw - "Вельможа Верхнього та Нижнього Сгипту" [Dodson 2009, 65]. Хоремхеб мав також військовий титул I my-r imyw-r mSanb-tAwy “Наглядач за генералами Володаря двох земель” [Dodson 2009, 65]. Ці титули прирівнювали його носія до статусу старшого сина фараона і згодом призначалися царевичам у часи правління династії Рамессидів. Еє, на противагу Хоремхебу, найчастіше згадується під титулом I t-nTr - “Божий батько”, i саме він посів при дворі 
Тутанхамона провідну позицію та зображувався біля фараона й Анхесенамон. Також Еє обіймав посаду візира при дворі Тутанхамона, одним 3 його титулів був * Aty iri mAat - "Візир, виконувач mA丸” [Dodson 2009, 99].

Вже за часів правління Тутанхамона розпочався демонтаж храмів його батька. У процесі нової будівельної програми при Тутанхамоні був здійснений проєкт із реставрації зображень бога Амона, які були знищені під час релігійної реформи фараона Ехнатона. При Тутанхамоні завершується будівництво центральної колонади Луксорського храму, яке було розпочате ще при Аменхотепі III. Існують археологічні підтвердження будівельної активності молодого фараона в Мемфісі, що став царською резиденцією після Ахетатона, судячи зі значної кількості розташованих тут гробниць аристократії [Dodson 2009, 72]. Незважаючи на зміну столиці, Ахетатон ще продовжував функціонувати як єгипетське місто до правління фараона Хоремхеба. У часи правління Тутанхамона було створено багато статуй богів з рисами обличчя молодого фараона, однак у мистецтві цього періоду ще відчувається вплив амарнського стилю [Robins 1994, 148-159].

Проте офіційна ідеологія, що була нав'язана молодому фараону керівною елітою, очевидно, розходилася з його особистими уподобаннями. Незважаючи на новий державний релігійний курс, Тутанхамон з роками ще продовжував шанувати сонячний культ свого батька, принаймні у приватних зображеннях. Зокрема, на золотому троні Cairo J.Е. 62028 із гробниці Тутанхамона KV 62 фараон і цариця зображені у класичному амарнському стилі під променями бога Атона, а ім'я молодого правителя зустрічається у двох варіантах: у новому Тутанх-амон та у старому Тутанх-атон, як і його дружини Анхесен-амон [Заплетнюк 2016, 324]. Повної заборони культу Атона при Тутанхамоні не відбулося, храми бога сонячного диска продовжували функціонувати в Ахетатоні та в усьому Єгипті.

Тутанхамон помер у віці 18-19 років і був похований у Долині царів у гробниці KV 62, яка, найімовірніше, не призначалася для фараона. Можливо, Тутанхамон будував для себе гробницю KV 57, яка згодом була узурпована Хоремхебом. Існує версія, що гробницею Тутанхамона мала стати KV 23, у якій був похований потім Ee [Drenkhahn 1983, 30].

Коли на 10-му році правління ії чоловік раптово помер, Анхесенамон залишилася останньою представницею царської династії. I давньоєгипетські джерела не відображають події, які дали змогу візиру Еє посісти престол, та не повідомляють, що сталося з самою Анхесенамон. Основним доказом легітимації влади Еє був археологічний звіт П. Ньюберрі, у якому продемонстровано копію персня із синього скла, на якому збереглися два царські картуші з іменами Еє та Анхесенамон. Ця так звана "обручка" чітко вказує на те, що Еє став царем Єгипту завдяки одруженню $з$ Анхесенамон [Newberry 1932, 50]. Існує також гіпотеза, що Еє був представником царської династії і тому мав права на египетський престол, наприклад, Еє міг бути батьком цариці Нефертіті [Aldred 1957] або регентом Тутанхамона [Seele 1955, 168-180].

Однак для розуміння ролі Анхесенамон у подіях узурпації влади Еє слід розуміти статус цариці в часи правління Тутанхамона. Н. Рівз, досліджуючи титулатуру Тутанхамона і Анхесенамон із гробниці KV 6, припустив, що їхне царювання більше було схоже на співправління двох правителів, ніж на традиційну модель: цар та 
цариця - консорт [Reeves 2005, 141]. Статус Анхесенамон підкреслювався титулами: N bt tAwy “Володарка двох земель” та M ry Wrt-Hkaw “улюблена Урет-хекау” [Еаton-Krauss, Graefe 1985, 23], богинею, яка була традиційно пов'язана 3 коронацією фараонів та легітимізацією влади. Подібна модель співправління була започаткована Ехнатоном та Нефертіті і могла бути прийнята за основу Тутанхамоном та Анхесенамон. Регентство та незалежне правління цариці Нефертіті, матері Анхесенамон, також було прикладом для молодої цариці, яка була прямою спадкоємицею трону свого батька та чоловіка.

Намагаючись утримати владу, Анхесенамон вирішує укласти політичний союз із хетським царем Суппілуліумою I, і саме це рішення свідчить про те, що в самому Єгипті їй протистояла сильна опозиція. У листі цариця Анхесенамон (у хетських джерелах вона називається Dahamunzu, можливо як інтерпретація титулу tA Hmtnsw - “дружина царя”) пише: “Мій чоловік помер, і я не маю сина. Але вони сказали, що ти маєш багато синів. Якщо ти віддаєш мені одного зі своїх синів, тоді він стане моїм чоловіком. Я не хочу вступати у шлюб зі своїм підданим. Я боюся" [Dodson 2009, 60]. Відсутність претендентів на престол, зі слів цариці, свідчить про те, що ні Еє, ні Хоремхеб не мали царського статусу та не були членами царської родини. I жоден з них не був оголошений спадкоємцем. Це була безпрецедентна подія, адже ніколи на престол Сгипту не запрошувались закордонні царевичі, до того ж хети перебували в напружених відносинах з Сгипетською державою.

Через те що в листі до хетського царя цариця згадується під іменем Dahamunzu, в історіографії довгий час точилася дискусія щодо ідентифікації єгипетської цариці, наприклад, в особі цариці Нефертіті [Redford 1967, 159-162] Ф. Бреєр, порівнявши аккадські та хетські правила транскрибування титулів та імен єгиптян, дійшов висновку, що ім'я померлого фараона в хетських джерелах збігається 3 тронним іменем Тутанхамона, і припустив, що посланник Суппілуліуми I був відряджений до Сгипту, щоб перевірити слова Анхесенамон, і подарував маленький кошик для поховання царя Тутанхамона [Breyer 2010, 447-449].

T. Р. Брайс також доводить, що лист відправила саме Анхесенамон, адже вона говорила про відсутність спадкоємця, що було б неможливо в разі, якби автором листа була Нефертіті, адже маленький Тутанхатон був офіційним спадкоємцем Ехнатона [Bryce 1990, 98]. А. Шульман також підтримав теорію ідентифікації Dahaтипzи як Анхесенамон, а не Нефертіті [Shulman 1978, 43-48].

Суппілуліума I відправив до Єгипту свого посланника, і після другого листа від Анхесенамон та підтвердження інформації, що в Єгипті немає спадкоємця, хетський цар відправив свого сина, принца Цаннанца, у Сгипет для царювання. Як зазначав Т. Брайс, “немислимо, щоб Суппілуліума I відправив свого сина до Єгипту без упевненості, що Тутанхамона не пережила будь-яка особа царського походження, яка могла б претендувати на престол" [Вryce 1990, 102]. Спроба цариці вийти заміж за хетського принца не увінчалася успіхом. Принц Цаннанца був убитий по дорозі до Єгипту.

Це погіршило і без того складну ситуацію в регіоні і призвело до воєнного конфлікту між Сгиптом та хетами. I нарешті Анхесенамон, ймовірно, була змушена вийти заміж за Еє, який став царем Сгипту. Однак надалі нам нічого не відомо про Анхесенамон, і офіційною дружиною Еє в його гробниці значиться Тея. Після цього Анхесенамон зникає з історії. Цікаво, що, коли Хоремхеб став фараоном, він 
розгорнув кампанію проти Анхесенамон і більшість іiі зображень з іiі іменем було знищено. Це свідчення його відвертої ворожості до цариці, можливо, було пов'язане з їі діями проти нього після смерті Тутанхамона [Kawai 2010, 289].

Отже, цариця Анхесенамон була активним історичним гравцем, вступивши в боротьбу за єгипетський престол маючи достатньо політичної влади, щоб укласти союз із хетами і зробити хетського принца царем Єгипту. Відстрочка поховання Тутанхамона [Bryce 1990, 104] та відправка хетського принца в Єгипет свідчать про відсутність офіційного спадкоємця, незважаючи на те що Еє і Хоремхеб пропагували ідею, що Тутанхамон призначав їх своїми спадкоємцями.

\section{ЛІТЕРАТУРА}

Заплетнюк О. А. Малий Гімн Атону // Сходознавство. 2014. № 67.

Заплетнюк $O$. А. Послаблення царської влади після смерті фараона Ехнатона. Єгипетська “контрреформація" // Молодий вчений. 2016. №. 3.

Заплетнюк О. А. Текст прикордонних стел "Раннього проголошення" Амарнського періоду // Сходознавство. 2020. № 85.

Breyer F. Egyptological remarks concerning Dahamunzu // Ägypten und Levante, 2010. Vol. 20.

Bryce T. R. The Death of Niphururiya and its Aftermath // The Journal of Egyptian Archaeology, 1990. Vol. 76.

Dodson A. Amarna Sunset: Nefertiti, Tutankhamun, Ay, Horemheb and the Egyptian Counter-Reformation. Cairo, 2009.

Dodson A. Nefertiti: Queen and Pharaoh of Egypt. Cairo, 2020.

Drenkhahn R. Eine Umbettung Tutanchamun? // Mitteilungen des Deutschen Instituts für Ägyptische Altertumskunde in Kairo. 1983. Bd. 39.

Eaton-Krauss M., Graefe E. The Small Golden Shrine from the Tomb of Tutankhamun. Oxford, 1985.

Hagen F. A sun-shade temple of Princess Ankhesenpaaten in Memphis? // The Journal of Egyptian Archaeology. 2011. Vol. 97.

Hornung E., Krauss R. and Warburton D. A. Ancient Egyptian Chronology. Lieden - Boston, 2006.

Kawai N. Ay versus Horemheb: The Political Situation in the Late of Eighteenth Dynasty Revisted // The Journal of Egyptian History. 2010. Vol. 3.

Murnane W. J. Texts from the Amarna Period in Egypt. Atlanta, 1995.

Murnane W. J., Charles C. van Siclen III. The Boundary Stelae of Akhenaten. London, 1993.

Newberry E. P. King Ay, The Successor of Tutankhamun // The Journal of Egyptian Archaeology. 1932. Vol. 18. 1967.

Redford D. History and Chronology of the Eighteenth Dynasty of Egypt. Toronto,

Reeves $N$. The Complete Tutankhamun. Cairo, 2005.

Robins G. Proportion and Style in Ancient Egyptian Art. Austin, 1994.

Seele $K$. C. King Ay and the Close of the Amarna Age // Journal of Near Eastern Studies. 1955. Vol. 14 (3).

Shulman A. R. Ankhesenamūn, Nofretity, and the Amka Affair // Journal of the American Research Center in Egypt. 1978. Vol. 15. 


\section{REFERENCES}

Zapletniuk O. A. (2014), "Malyy Himn Atonu”, Shodoznavstvo, No. 67, pp. 39-46. (In Ukrainian).

Zapletniuk O. A. (2016), "Poslablennya tsarskoy vladu pislya smerti faraona Ehnatona. Yegupetska "kontrreformaciya", Moloduy vchenuy, No. 3, pp. 320-5. (In Ukrainian).

Zapletniuk O. A. (2020), "Tekst prukordonnuh stel 'Rannyogo progoloshennya' Amarnskogo Periodu”, Shodoznavstvo, No. 85, pp. 69-104. (In Ukrainian).

Breyer F. (2010), "Egyptological remarks concerning Dahamunzu", Ägypten und Levante, Bd. 20, pp. 445-51.

Bryce T. R. (1990), "The Death of Niphururiya and its Aftermath", The Journal of Egyptian Archaeology, Vol. 76, pp. 97-105.

Dodson A. (2009), Amarna Sunset: Nefertiti, Tutankhamun, Ay, Horemheb and the Egyptian Counter-Reformation, The American University in Cairo Press, Cairo.

Dodson A. (2020), Nefertiti: Queen and Pharaoh of Egypt, The American University in Cairo Press, Cairo.

Drenkhahn R. (1983), “Eine Umbettung Tutanchamun?", Mitteilungen des Deutschen Instituts für Ägyptische Altertumskunde in Kairo, Bd. 39, pp. 29-37.

Eaton-Krauss M. and Graefe E. (1985), The Small Golden Shrine from the Tomb of Tutankhamun, Griffith Institute, Oxford.

Hagen F. (2011), “A sun-shade temple of Princess Ankhesenpaaten in Memphis?", The Journal of Egyptian Archaeology, Vol. 97, pp. 216-22.

Hornung E., Krauss R. and Warburton D. A. (2006), Ancient Egyptian Chronology, Brill, Lieden and Boston.

Kawai N. (2010), "Ay versus Horemheb: The Political Situation in the Late of Eighteenth Dynasty Revisted”, The Journal of Egyptian History, Vol. 3, pp. 261-92.

Murnane W. J. (1995), Texts from the Amarna Period in Egypt, Writings from the Ancient World, Book 5, Society of Biblical Literature, Atlanta, GA.

Murnane W. J. and Van Siclen C. C. (1993), The Boundary Stelae of Akhenaten, Kegan Paul International, London.

Newberry E. P. (1932), "King Ay, The Successor of Tutankhamun", The Journal of Egyptian Archaeology, Vol. 18, pp. 50-2.

Redford D. (1967), History and Chronology of the Eighteenth Dynasty of Egypt, University of Toronto Press, Toronto.

Reeves N. (2005), The Complete Tutankhamun, The American University in Cairo Press, Cairo.

Robins G. (1994), Proportion and Style in Ancient Egyptian Art, University of Texas Press, Austin.

Seele K. C. (1955), "King Ay and the Close of the Amarna Age", Journal of Near Eastern Studies, Vol. 14 (3), pp. 168-80.

Shulman A. R. (1978), "Ankhesenamūn, Nofretity, and the Amka Affair”, Journal of the American Research Center in Egypt, Vol. 15, pp. 43-8.

\section{B. А. Заплетнюк}

\section{ЦАРЫЦА АНХЕСЕНАМОН І КРЫЗІС АМАРНСКАЙ ДЫНАСТЫІ}

Артыкул прысвечаны даследаванню ролі старажытнаегіпецкай царыцы Анхесенамон у палітычным крызісе ў Старажытным Егіпце ў пост-Амарнскі перыяд, а таксама ўплыву яе 
дзейнасці на міжнароднае становішча на Блізкім Усходзе. Анхесенамон (Анхесепаатон) (прыбл. 1345-1323 гг. да н. э.) была ключавой фігураю ў пост-Амарнскі час у барацьбе за егіпецкі прастол, што прывяло да яго ўзурпацыі візірам Эйе і да падзення Амарнскай дынастыі. Нягледзячы на тое, што ў гістарыяграфіi Анхесенамон застаецца ў цені свайго знакамітага мужа Тутанхамона ды яго паслядойнікаў, археалагічна і наратыўна крыніцы сведчаць пра тое, што яна вяла актыўную барацьбу за ўладу ды дзейнічала як законны спадчыннік і кіраўнік. Аўтар робіць выснову, што наяўнасць супрацьстаяння паміж Анхесенамон, Эйя i Харэмхебам за трон Тутанхамона паказвае на тое, што ні Эйя, ні Харэмхеб не былі прадстаўнікамі царскай дынастыі і не мелі правоў на егіпецкі прастол.

Ключавыя словы: Старажытны Егіпет, Анхесенамон, Тутанхамон, Амарнскі перыяд, Эхнатон

\section{О. А. Заплетнюк}

\section{ЦАРИЦЯ АНХЕСЕНАМОН ТА КРИЗА АМАРНСЬКОЇ ДИНАСТІЇ}

Стаття присвячена дослідженню ролі давньоєгипетської цариці Анхесенамон у політичній кризі в Стародавньому Сгипті в Постамарнський період та впливу ії діяльності на міжнародну ситуацію на Близькому Сході. Анхесенамон (Анхесенпаатон) (бл. 1345-1323 до н. е.) була ключовою постаттю в Постамарнську добу в боротьбі за єгипетський престол, що призвело до його узурпації візиром Еє і до падіння Амарнської династії. Незважаючи на те що в історіографії Анхесенамон залишається в тіні свого знаменитого чоловіка Тутанхамона та його наступників, археологічні та наративні джерела свідчать про те, що вона вела активну боротьбу за владу та діяла як законна спадкоємиця і правителька. Авторка робить висновок, що наявність протистояння між Анхесенамон, Еє та Хоремхебом за трон Тутанхамона вказує на те, що ні Еє, ні Хоремхеб не були представниками царської династії і не мали прав на єгипетський престол.

Ключові слова: Стародавній Єгипет, Анхесенамон, Тутанхамон, Амарнський період, Ехнатон 